Anuario Latinoamericano Ciencias Políticas y Relaciones Internacionales vol. 7, 2019

pp. 279-296

\section{The Efforts to Combat Organized Crime in Brazil}

DOI: 10.17951/al.2019.7.279-296

\section{Los esfuerzos para combatir el crimen organizado en Brasil}

\author{
Edyta Chwiej* \\ INSTITUTE OF POLITICAL SCIENCE AND INTERNATIONAL RELATIONS \\ JAGIELLONIAN UNIVERSITY \\ CRACOW, POLAND \\ $\triangle$ edyta.chwiej@uj.edu.pl \\ https://orcid.org/0000-0003-1298-1822
}

\begin{abstract}
In recent decades organized crime has ceased to be an isolated issue concerning only a single country. The negative consequences of this phenomenon spread out of the state borders and cause a danger for public security, democratic institutions and economic stability. The struggle against organized crime requires the coordinated cooperation of the law enforcement, judiciary and other institutions responsible for the prevention, detection, prosecution, and sanctioning of the criminal activity.

The article studies some aspects of this phenomenon in Brazil. It discusses the factors that have contributed to the development of organized crime in this most influential country of South America. The paper also examines various initiatives that have been taken by Brazilian authorities in the efforts to combat organized crime.
\end{abstract}

KEYWORDS: organized crime, Brazil, struggle against organized crime, violence.

\section{RESUMEN}

En las últimas décadas el crimen organizado se ha convertido en un importante problema para la seguridad internacional. La delincuencia organizada representa una gran amenaza para la seguridad pública, a las instituciones democráticas y para la estabilidad económica. La lucha contra este fenómeno requiere la cooperación policial y judicial en materia de prevención, detección, investigación y sanción de los delitos cometidos por organizaciones criminales.

El artículo presenta y analiza algunos aspectos relevantes del crimen organizado en Brasil. Además, describe los factores que han influido en el desarrollo de la delincuencia organizada en este país. El artículo examina también las iniciativas tomadas por las autoridades brasileñas para combatir el crimen organizado.

PALABRAS CLAVE: crimen organizado, Brasil, lucha contra crimen organizado, violencia.

${ }^{*}$ M.A. and Ph.D. in Political Science at the Jagiellonian University. Assistant Professor at the Institute of Political Science and International Relations, Jagiellonian University. Departmental Coordinator of Erasmus Plus Programme. 


\section{Introduction}

In recent years organized crime has become an important transnational problem affecting the global system and international relations. It is estimated to generate 870 billion dollars a year, an amount equal to 1.5 percent of global GDP (UNODC 2011), through illegal activities such as human trafficking, the smuggling of migrants, illicit drugs, environmental crime, illegal arms, etc.

There is no generally accepted definition of this phenomenon. Even the United Nations Convention against Transnational Organized Crime, adopted by General Assembly on the $15^{\text {th }}$ November 2000, does not contain a precise definition of organized crime (UNODC 2004). This lack of definition was intended to allow for a broader applicability of the Convention to new types of crime, because organized crime is flexible and capable of adopting itself very quickly to new environments.

\section{Organized crime in Brazil - determinants}

In 2013, Brazilian authorities proposed their own definition of organized criminal group. According to Law No 12850, it is a structured group of four or more persons, characterized by the informal division of tasks, acting in order to obtain, directly or indirectly, a financial or other material benefit for an offence punishable by a penalty involving deprivation of liberty of at least four years or for an offence of the transnational character (Lei No 12850).

Some authors suggest that origin of organized crime in Brazil relates to criminal phenomenon known as cangaço from the late $19^{\text {th }}$ and early $20^{\text {th }}$ centuries. This term was used to an organized band of poor peasants who inhabited the Northeast Brazil. It was a form of "social banditry" against the government. The bands very often invaded cities and small villages in order to rape, rob and commit homicides (Oliveira Fernandes 2012: 46-47).

Other experts draw attention on the jogo do bicho, an illegal gambling game which had grown into a lucrative business and exerted a significant impact on the Brazilian organized crime. It was created in 1892 by baron João Batista Viana de Drummond, who opened first zoo in Rio de Janeiro. To attract customers, he started a daily raffle with gate prizes (Long 1988). The raffle soon became the lottery and because of the link between the 25 animals in the zoo and the numbers the lottery became known as a jogo do bicho - "the animal lottery" (Casas-Zamora 2013: 45). According to Law No 3688 of 1941, the game was raised to the category of a penal crime. However, the law has not been rigorously enforced and due to its huge popularity the jogo do bicho has expanded during the $20^{\text {th }}$ century throughout the country. Nowadays it is organized by a small group of entrepreneurs in each state (Roth 2017:381) and it is estimated to be a 3.7 billion dollars business annually (Pearson 2016). According to Bruno Wilhelm Speck, jogo do bicho is also a territorial crime, with 
local bosses fighting for control of this illegal business. The leaders of these criminal organizations are called bicheiros (Casas-Zamora 2013: 46). The bosses invested part of their enormous earnings in activities like the financing of samba schools and football clubs. But other than that, bicheiros have expanded their business into illegal activities like prostitution, money laundering and murders (The Economist 2012).

At the beginning of the 1970s, with the entrance of large quantities of cocaine into Brazil, links began to emerge among bicheiros, Colombian drug cartels and local criminal groups. Brazil became an important transshipment point for drugs, destined for the United States and Europe, and an important local drug market (Penglase 2014: 16). It is worth adding that the Federative Republic of Brazil shares half of its $16145 \mathrm{~km}$-long borders with the world's three biggest cocaine producers: Bolivia, Colombia and Peru. According to experts, Brazil is the world's second largest consumer of cocaine and crack, behind only the United States, and accounts for twenty percent of the worldwide market for cocaine and its derivatives (Jordan 2012). Moreover, cocaine is shipped from Brazil to Africa and to European markets. The port of Santos is a major transshipment center for the drugs - it is estimated that around 80 percent of the cocaine arriving in Europe transits through Santos (Woody 2018).

Some authors suggest that there is a strong relationship between factors such as social exclusion, poverty, income inequality and the incidence of crime in Brazil. Brazil has made a considerable progress in reducing poverty and improving living conditions from the beginning of the $21^{\text {st }}$ century. In the same time, GDP per capita (at Purchasing Power Parity) has risen by 68 percent (World Bank 2018). Nevertheless, the high level of income inequalities is still one of the most widely recognized aspects of Brazilian society. For instance, GINI Index in Brazil was reported at 51,3 in 2015 and it was the $19^{\text {th }}$ highest out of 156 countries worldwide (CIA The World Factbook). Another example: it is estimated that six richest people in Brazil have the same wealth and equity as the 100 million poorest Brazilians (Margolis 2017).

The Brazilian Institute of Geography and Statistics (IBGE) shows that $25.4 \%$ of the Brazilian population, more than fifty-two million, live in extreme poverty, according to the criteria established by the World Bank. Moreover, there is a significant correlation between social exclusion and ethnicity and colour. The residents of housing units formed by black or brown women, without a partner, with children aged up to 14 are the most at risk of poverty (Agência IBGE 2017).

Authors point out that improvement of some social indicators, like life expectancy (from 65.3 years in 1990 to 75.7 years in 2017) (UNDP 2018), illiteracy (percentage of persons aged 15 and over, who can read and write has grown from 74.6 in 1980 to 91.7 in 2014) (World Bank 2015) or access to sanitary service and education does not lead to lower crime rate.

In 2017, Brazil beat its own previous record (from 2016) for homicides - 63,880 people were murdered (Darlington 2018). The average national ho-
The Efforts to Combat Organized Crime in Brazil

Edyta Chwiej 
Artículos y ensayos

Graph 1.

Homicide rate in Brazil 2000-2017 (per 100,000)

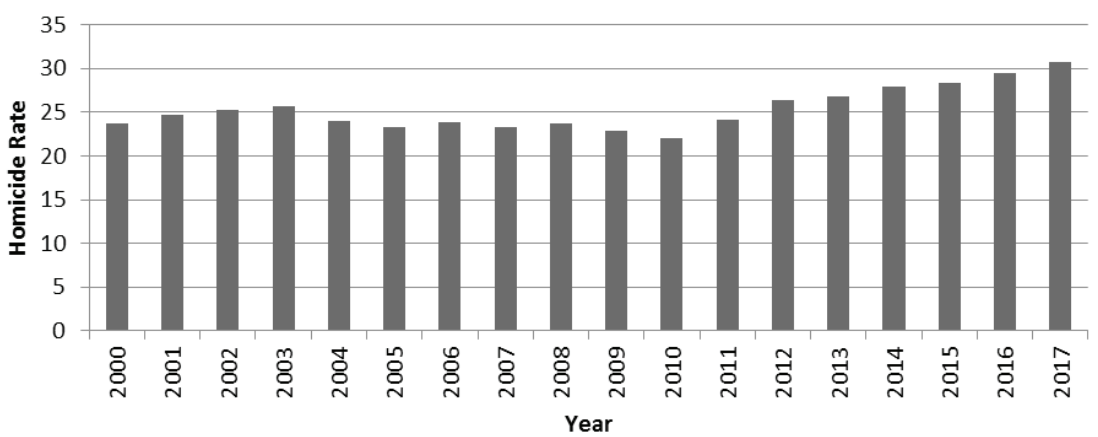

Source: own elaboration on the basis of Intentional homicides (per 100,000 people), World Bank, https://data.worldbank.org/indicator/VC.IHR.PSRC.P5?locations=1W, access: 3.10.2018; Stargardter, Berlowitz (2018).

micide rate was 30.8 killings for every 100,000 people (see Graph 1). Most of the homicides occurred in urban centers, particularly in the poorest states of the North and Northeast regions. The state of Rio Grande do Norte had the highest murder rate in 2017, with 68 murders per 100,000 people, followed by Acre, with 63.9 per 100,000 people and Ceará, with 59.1 per 100,000 people (Stargardter, Berlowitz 2018). These rates were two times higher than the national average. More than 90 percent of homicide victims were men, and the age group of 15 to 29 years accounted for nearly 60 percent of all victims (Waiselfish 2016: 49). What is more, for every 100 Brazilians that are killed, 71 of them are black or mixed race (CNN Español 2018).

Some authors indicate the influence of such factors like social inequality, a low level of education, a lack of access to good-paying jobs, the zona/ neighborhood of living and a colour of the skin on the level of violence. In their opinion, these factors relate mainly to Afro-Brazilians, who historically had access to very poor-quality education, which resulted in the lack of possibility to find a high-paying job. Higher levels of economic poverty increase the chances of this population living in poor and stigmatized neighborhood (Kassab, Rosen 2018: 16). The members of the gangs very often are recruited from among such people. For instance, the non-governmental organization Observatório de Favelas has been analyzing, from the beginning of the $21^{\text {st }}$ century, the profile of people, who work for criminal organizations in Rio de Janeiro. According to their surveys, examined gangs have been mainly composed of young black or mixed-race men, born into big families - usually led by a woman - of lower income, who dropped out of school and had experiences with precarious jobs before getting into crime (The Brazilian Report 2018).

It is believed that the defective penitentiary system has also influenced the development of the organized crime in Brazil. This is illustrated by the fact, that the most powerful criminal groups, including Primeiro Comando da $\mathrm{Ca}-$ pital (PCC) and Comando Vermelho (CV) were founded in prisons. 
Comando Vermelho is the oldest of Brazil's major criminal organizations. It was born out of an alliance between common criminals and leftist militants, imprisoned in Candido Mendes prison (Ilha Grande island) under the military dictatorship (1964-1985). By 1979, the group had spread out of the prison and had been operating in the slums of Rio de Janeiro. Members who were on the outside were tasked with providing money to those on the inside through criminal activities (InSight Crime 2018). In 1980, the prison authorities transferred several members of the CV to other prisons in Rio de Janeiro state. As a result, the CV's organizational methods and ideology were spreading very rapidly to all of Rio's prisons (Kontos, Brotherton 2008: 16). Nowadays Comando Vermelho sells cocaine and other drugs in the slums under its control (mainly in Rio de Janeiro) (Ellis 2018: 89).

Primeiro Comando da Capital is the Brazil's largest criminal organization, with an estimated 30,000 members (Adorno, Costa 2018). The PCC was formed in the wake of the most tragic prison riot occurred in Casa de Detenção de São Paulo ("Carandiru") on the $2^{\text {nd }}$ of October 1992, in which Brazilian policy forces killed 111 prisoners (Kontos, Brotherton 2008: 18). Initially, it was a self-defense and advocacy organization in response to prison conditions (Ellis 2018: 88). Since its inception in the beginning of 1990s, the power of PCC grew steadily, reaching its height in 2006 (Albanese, Reichel 2014: 69). On the $12^{\text {th }}$ of May 2006, the criminal organization launched a coordinated series of more than 250 attacks in about seventy prisons across São Paulo state in protest after the transfer of some members of PCC to remote facilities. Moreover, gang leaders ordered the supporters outside the prison to organize attacks on police headquarters, buses and public buildings. The five-day series of attacks resulted in 115 deaths, including 40 police/prison guards, 71 suspected gang members and 4 civilians (Prada 2006). Nowadays, Primeiro Comando da Capital is considered to be one of the most important criminal organizations in South America, with significant influences in Bolivia, Paraguay and Peru (Ellis 2018: 89).

The chronic overcrowding is one of the most serious problems facing Brazil's penal system. The country is now ranked third among countries in the world with the most people in prison, behind only the United States and China (ICPR 2018). From the beginning of the $21^{\text {st }}$ century, Brazil's prison population has risen three times, from 232,755 to 690,722 prisoners (ICPR Brazil 2018). This massive rise of the prison population has been associated mainly with two trends: the expanding use of pre-trial detention and harsh punishment for drug use and possession (Leeds 2016). Furthermore, human rights defenders draw attention to bad prison conditions, including poor sanitation, inadequate access to food or potable drinking water, poor medical care, mistreatment of prisoners by prison staff or even the tortures (HRW 2013). All these factors create a fertile ground for organized criminal activities. According to experts, Brazil's prisons are largely controlled by gangs and very often gang leaders continue to run their criminal networks from their prison cells (Flynn, Palermo 2017).
The Efforts to Combat Organized Crime in Brazil

Edyta Chwiej 
According to estimates, from 1996 to 2015 the economic costs of organized crime in Brazil doubled, from 113 billion reais to 285 billion reais. In 2015, the total cost of public security, private security, insurance and productive losses, juridical processes, loss of capacity, imprisonment and medical expenditures related to crime costs amounted to 4.38 percent of Brazil's gross domestic product (Secretaria-Geral da Presidência 2018).

\section{Fighting against organized crime}

As it has already been mentioned, in the 1980s and 1990s, organized crime in Brazil has risen markedly. For this reason, the legislative changes were introduced to allow the effective prosecution of organized crime and fight against drug trafficking (Godoy 2017).

In 1995, the Brazilian authorities adopted Law No 9034, which defined and regulated evidentiary and investigative procedures relating to crimes arising from the activities of criminal groups or bands (Lei No 9034). It provided new tools for the law enforcement, such as controlled action (delaying the arrest of a suspect until a better moment in order to obtain evidence) or free access to fiscal, banking, financial and electoral documents and information (Costa 2007:77). The next legal act, Law No 10217, adopted in 2001 (Lei No 10217), modified Law 9034 and added new instruments in the fight against organized crime groups, such as electronic surveillance and wiretapping or undercover operations (Costa 2007:72). However, Law No 9034 and Law No 10217 did not contain a precise definition of "organized crime".

In 2013, Brazilian authorities adopted the above-mentioned Law No 12850, which defines "criminal organization", provides regulations for criminal investigation, the means for obtaining evidence and the criminal trial procedure which can be applied to such organizations. This Law also applies to the criminal offences recognized by international treaties or conventions, when the criminal activity is initiated in Brazil and the result has occurred or should have occurred abroad; and vice versa.

Promoting, constituting, financing or integrating a criminal organization, directly or indirectly, is punishable by deprivation of liberty for the term of 3 to 8 years. The punishments are increased if the actions of the criminal group involve the use of firearms or if a person leads a criminal organization. Apart from the means already established by law, the following means of evidence collection are allowed: conclusion of plea bargaining agreements; capture of electromagnetic, optical or acoustic signals; controlled action; access to the bank, financial and fiscal secrecy; infiltration by police officers performing activities of investigation or cooperation among institutions and federal, district, state, and municipal organs in search of evidence and information of interest for the investigation or criminal proceedings. 
The Brazilian legal system established other important legal provisions relating to preventing and combating organized crime. There are several examples that could be mentioned:

- The Brazilian Criminal Code - Law No 2848 of 1940

- Law for the Protection of Victims and Witnesses - Law No 9807 of 1999

- Money Laundering Law - Law No 9613 of 1998; amended in 2012 (Law No 12683)

- Law No 11343 of 2006, creating the National System for Public Policies on Drugs.

The fight against organized crime requires strong collaboration between the public security institutions. According to the Constitution of the Federative Republic of Brazil of the $5^{\text {th }}$ of October 1988 (article 144), the following agencies are responsible for maintaining public order and the safety of persons and property: the Federal Police, the Federal Highway Police, the Federal Railway Police, the State Civil Police, the State Military Police and Fire Brigade (Constituição da República Federativa do Brasil de 1988). The Federal Police (around 15,000 members; Muggah 2016: 7) are intended to investigate criminal offenses against the union, Brazilian federal government, its organs and companies, fight against interstate or international crime, prevent and repress smuggling and drug trafficking and protect the country's borders.

However, some experts point out that Constitution assigns to the state police forces the responsibility for the investigation of the vast majority of criminal activities (Costa 2007: 70). The state police are divided into the Civil (some 123,403 members) and Military Police (over 400,000 active members; Muggah 2016: 7). The Military Police units are the uniformed forces which patrol the streets and maintain public order (Costa 2007: 70). The Civil Police investigate crimes and prepare cases for prosecution (Riccio, Skogan 2017: 9).

According to Ignacio Cano, through the division into the Civil and Military Police, "neither force carries out the 'complete cycle' of public security, from prevention to combating crime, which leads to problems of overlap and of rivalry between them" (Cano 2006). This researcher also indicates other problems, which could make the fight against organized crime less effective: insufficient investment, leading, among others, to poor wages for the lower ranking police officers, poor training for police officers and high degree of corruption in the public security institutions (Cano 2006).

Another author, John Crocitti, states that policemen's salaries (mainly in the Military Police) are often a few dollars above the minimum wage and some of the policemen work additionally as private security guards or as "militiamen" (Crocitti 2012: 486). Militias (milícias) are groups, which often include former and current armed state agents (policemen, prison guards, firemen, etc.). At the beginning of the $21^{\text {st }}$ century, these groups started operating in Rio de Janeiro (Phillips 2018) and they have taken control of small territories, charging residents and small business owners a fee for the "protection" of them, and monopolizing most economic services (like supply of water and gas, or Internet
The Efforts to Combat Organized Crime in Brazil

Edyta Chwiej 
services) (Cano 2013: 183). For many residents, the militias are the "lesser evil", because they also reduce street crime and drug dealing. However, in reality most of them are involved in the organized crime activities (Barrionuevo 2008).

Non-governmental organizations point out that the fight against organized crime in Brazil is sometimes connected with undue violence of police, unlawful killings and mistreatment of detainees (HRW 2017). At least 5,012 people were killed by the police in Brazil in 2017, according to the Brazilian Forum for Public Security'; it was 19 percent more than in 2016. At the same time, the number of murdered police officers has fallen by 15 percent to 385 (Velasco, Caesar, Reis 2018).

On the other side, many police officers complain about low pay, old equipment, unstable employment and hard-working conditions (Thaty, Doederlein 2017; Resende 2018). The policemen also point out that they risk their lives every day, but their work is unnoticed and undervalued. On the contrary, their errors are scrutinized and overexposed in the mass media. Moreover, Brazilian policemen complain about the impunity of criminals and the inefficiency of judicial institutions (Barbara 2014).

Besides the law enforcement, the primary institutions of the criminal justice system are prosecution, defense lawyers and the courts. According to the Constitution (article 92), the organs of the Judiciary Power are the Federal Supreme Court, the Superior Court of Justice, Regional Federal Courts and the Federal Judges, the specialized courts (Labour, Electoral, and Military) and Judges, the Courts and Judges of the States, of the Federal District and of the territories. The Federal Supreme Court is the highest judicial authority. It is responsible, above all, for safeguarding the Constitution. Among other duties, it has also jurisdiction to prosecute and judge in case of criminal offenses committed by the President of the Republic, the Vice-President, the members of the National Congress, its own Judges, the Attorney-General, the Ministers of state and the Commanders of the Navy, the Army, and the Air Force. Moreover, it has original jurisdiction to decide extradition requests from foreign States (article 102).

Below the Federal Supreme Court is the Superior Court of Justice, whose responsibility is to standardize the interpretation of federal law. It also has the power to prosecute and judge in criminal cases which concern the Governors of the states and of the Federal District, its own Judges, the Judges of the Federal Regional, Electoral and Labour Courts, members of local account courts and members of the Federal Public Prosecutor Office. Additionally, it is the highest court of appeal for cases with non-constitutional subjects (article 5). The Federal Supreme Court and the Superior Court of Justice have jurisdiction over the Federal and State Courts. In the first instance, the cases (civil and criminal) are analyzed by Federal or State Judges. Appeals are then sent to the Regional Federal Courts, the Courts of Justice, and the Courts of Appeal - the final two organs in the State Courts.

\footnotetext{
1 Fórum Brasileiro de Segurança Pública - non-governmental organization set up in 2006.
} 
According to article 127 of the Constitution, the Public Prosecution is a permanent institution, whose task is to defend the juridical order, the democratic regime and the inalienable social and individual interests. It operates at federal and state level. The Federal Public Prosecutors act in the Federal Courts, investigating and prosecuting federal crimes (e.g., international drug trafficking, money laundering, smuggling, human trafficking, environmental crimes) and the crimes committed by the employees of federal institutions. The State $\mathrm{Pu}$ blic Prosecutors, acting in the State Courts, investigate and prosecute murders, robberies, frauds, and all the offenses not reserved to the other Courts (Borges de Mendonça 2014: 63-64).

In accordance with the Constitution, the arrested person shall be entitled to have the assistance of a lawyer. Moreover, the State shall provide full and freeof-charge legal assistance for low income population (article 5). Brazilian citizen must prove a lack of financial resources in order to obtain a free assistance from the Public Defender office, organized at the federal or state level. This legal assistance can, among others, defend the citizen in civil or criminal cases before the Judiciary and present appeals to tribunals or judge cases.

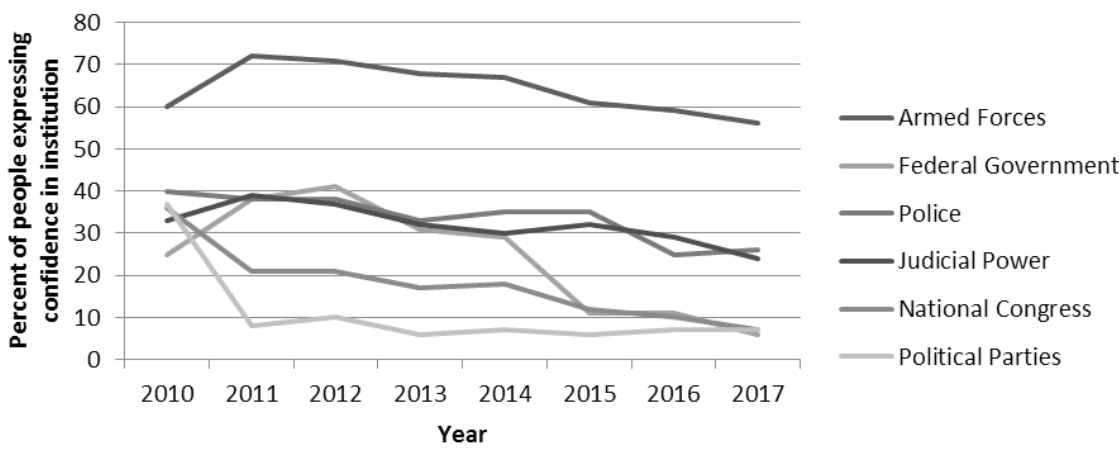

Source: own elaboration on the basis of Índice de Confiança na Justiça Brasileira (Relatório 4/2010, 2/2011, 2/2012-1/2013, 2/2013-1/2014, 1-4/2014, 2/2015, 1/2016, 1/2017), Escola de Direito de São Paulo da Fundação Getulio Vargas, https://direitosp.fgv.br/publicacoes/ icj-brasil, access 11.01.2019.

The increase in homicide rate, corruption scandals ${ }^{2}$ and the recent economic recession have reduced the level of public trust in Brazilian institutions. This is shown by the results of the survey on Justice Confidence Index ("Índice de Confiança na Justiça”). This Index reveals a drop in public confidence in all the most important institutions (see Graph 2). According to its data, the most

2 The corruption scandal "Car Wash Operation" (Operação Lava Jato) launched in 2014, the arrest of the former President Luiz Inácio Lula da Silva in 2018, the corruption charge against President Michel Miguel Elias Temer Lulia, among others.
The Efforts to Combat Organized Crime in Brazil

Edyta Chwiej

\section{Graph 2.}

The level of citizen trust in selected Brazilian institutions, according to Justice Confidence Index (2010-2017) 
trustworthy institution for the Brazilians is the military. In 2017, about 56 percent of respondents claimed to trust the Armed Forces and only 6 percent declared trust in the Federal Government. Public confidence and trust in Police were very low in 2017 - about 26 percent of respondents expressed confidence in this institution, compared with 40 percent in 2010. The Brazilians also have low confidence in their Judicial Power. In 2017, only 24 percent of surveyed respondents said that they trust in this Power (see Graph 2). Due to the increase in violence and the decline in confidence in Police, the Brazilians and the citizens of other Latin American countries are in favor of using military forces to fight against organized crime (Pion-Berlin, Carreras 2017: 8). According to Complementary Law No 97 of $1999^{3}$, the decision on using the armed forces to guarantee law and order is the President's responsibility. The President of Brazil can do that on his (her) own initiative or as a request from any of the constitutional powers. Law clearly defines that for public security purposes the armed forces should be used only exceptionally, when the instruments provided for it in the Constitution have been exhausted (Lei Complementar No 97). Moreover, Brazilian Armed Forces are also responsible for the preventive actions against cross-border and environmental crimes. They cooperate with the federal institutions, providing logistics and intelligence support. They can use various measures, including air, land and river patrols, searching of vessels, motor vehicles, people and aircraft or arrest in flagrante delicto. Since the Constitution was enacted in 1988, up to now the armed forces have been intervening "for the guarantee of law and order" during strikes (e.g., 1995 and 2001), during the visits of foreign dignitaries, political summits and sports events (e.g., the 1992 "Rio de Janeiro Earth Summit", the 2014 World Cup, the 2016 Summer Olympics) and assisting police forces in favelas to curb the drug trade and other violent crimes in major cities (Samset 2014: 9). The first intervention of the armed forces in favelas took place in Rio de Janeiro in 1994 and in 1995. Nevertheless, "Operation Rio 1994-1995" did not bring the expected results - the intervention did not reduce crime and the cases of abuse of power were being reported (Folha de S. Paulo 1994). Brazilian Armed Forces have also been involved in the Favela Pacification Program. This project was launched in 2008 in order to take back state control of Rio de Janeiro favelas. There were a few phases of "pacification": the introduction of a large number of security forces to clear the favela areas from the crime groups, implementation of the Pacification Peace Units (UPP) to establish a permanent police presence, implementation of the UPP Social to introduce the program, delivered by the municipal government in order to re-integrate residents of pacified favelas back into the city through access to public and private services (Carvalho, Berg, Galal, Teunisse 2017: 115-117). In December 2010, the Brazilian Ministry of Defense, in agreement with the Government of the State of

3 Amended by Complementary Law 117 of the $2^{\text {nd }}$ of September 2004 and Complementary Law 136 of the $25^{\text {th }}$ of August 2010 . 
Rio de Janeiro, formed "Pacification Forces". They were supposed to cooperate with the state forces to ensure the safety of the population, until the Police Pacification Units could be installed in two favelas of Rio de Janeiro: Complexo da Penha and Complexo da Alemão (Diretriz Ministerial No 15/2010) ${ }^{4}$. Once again, "Pacification Forces" were used to fight against organized crime in Complexo da Maré (the North Zone of Rio de Janeiro) between April 2014 and June 2015 (Kassab, Rosen 2018: 20-21).

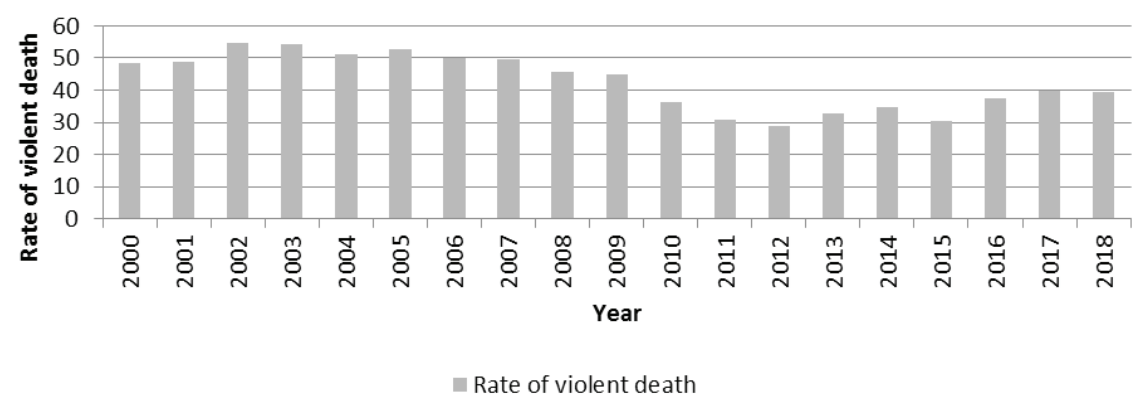

Source: own elaboration on the basis of Séries históricas anuais de taxa de letalidade violenta no estado do Rio de Janeiro e grandes regiões, Instituto de Segurança Pública, 2019, http:// www.ispdados.rj.gov.br/Arquivos/SeriesHistoricasLetalidadeViolenta.pdf access 1.02.2019.

For the first few years the Favela Pacification Program has generated positive outcomes: the security of people has improved and the number of reported violent deaths in pacified favelas decreased; e.g. in 2012 the rate of violent death was 29 per 100,000 Rio de Janeiro State residents, in comparison with 49 per 100,000 in 2000 (see Graph 3). But nowadays, the rise of violent crime in Rio de Janeiro as well as at the national level can be observed. According to experts, it has been caused by Brazil's economic recession, by the corruption scandals and by fierce competition among drug trafficking organizations. Moreover, the lack of serious follow-up investments because of economic recession have influenced on decline in support for the Program among the residents of favelas (Dias Carneiro 2017). After months of escalating violence in Rio de Janeiro and the mass robberies during Carnival, President Michel Temer signed Decree No 9288 on the $16^{\text {th }}$ of February 2018. This document allowed the federal government to intervene militarily in the Brazil's second largest city in order to guarantee the public security. Authorities appointed General Walter Souza Braga Netto to the position of federal intervener in Rio de Janeiro (Decreto No 9288). The intervention, ended on the $31^{\text {st }}$ of December 2018, has been positively assessed by General Braga Netto. From March to November the number of homicides in Rio de Janeiro dropped by 6 percent, the number of robberies of cargo-carrying
The Efforts to Combat Organized Crime in Brazil

Edyta Chwiej

\section{Graph 3.}

The rate of violent deaths in the State of Rio de Janeiro (2000-2018)

\footnotetext{
4 They operated from December 2010 to July 2012.
} 
vehicles fell by 20 percent, auto theft declined by 8 percent and street robberies - by 6 percent. At the same time, the number of people killed in police operations increased by about 38 percent and more than 90 police officers were killed in 2018 (Alves 2018). However, some experts believe that military intervention will not solve the problem of violence and insecurity in Rio de Janeiro. In their opinion, the authorities have opted for the easy and fast solutions, in response to the citizen demand for the effective security measures and they have sent army troops to the streets. But the struggle against organized crime requires the long-term strategies, instead of the short-term solutions, offered by the state (Muggah 2018). The current Brazilian authorities also try to face these challenges. The new President Jair Messias Bolsonaro promised, during his campaign, the determined fight against corruption and organized crime. The signing by President, on the $15^{\text {th }}$ of January 2019, of a decree easing restrictions on civilians to possession of firearms was the first step towards keeping his promises (Mazui, Barbiéri 2019). Moreover, the new Minister of Justice and Public Security, Sérgio Fernando Moro, has presented the project of a new anti-crime bill. The proposed changes include obligating convicts to begin serving their sentences after the first appeal is denied, recognizing of militias and drug trafficking gangs as organized criminal groups and fighting with illegal campaign financing. The first amendment relates mainly to wealthy and well-connected people, who - despite the judicial sentence - have remained free, while their appeals have been going on through courts. Furthermore, the bill would grant more protection to police officers who kill during operations, by specifying the situations that could be considered as defensive actions. The courts could reduce the sentence to half or cause an acquittal if the self-defense act happens due to "reasonable fear, surprise or violent emotion" (Mattoso, Della Coleta 2019). The project also includes tougher penalties for notorious criminals and introduction of strict security measures in prisons for the leaders of violent gangs (The New York Times 2019). Many experts and politicians praise the project of anti-crime bill. They believe there is a need to introduce the legislative reforms for improving the quality and efficiency of the Brazilian judicial system. They also support the measures proposed for combatting financial crimes and the efforts to reduce widespread impunity enjoyed by perpetrators of crimes (Melo, Miotto 2019). On the other hand, they voice their concerns about the practical application of a more lenient definition of self-defense. However, the Minister Moro ensures that the new self-defense bill "is not a license to kill" (Mattoso, Della Coleta 2019). Moreover, in the opinion of the Brazilian Forum for Public Security, the project makes no reference to some important issues, like the changes in functioning of police at both state and federal level or the fight against police corruption (UOL Notícias 2019). The final form of the future anti-crime law will be known after consultation with experts and the political groups and after receiving the approval of the National Congress. 


\section{Conclusions}

The fight against organized crime is the one of the most important priorities for the Brazilian government. In recent years, the authorities have introduced many important public security and justice reforms. They ratified the United Nations Convention Against Transnational Organized Crime and adopted a new law. Moreover, Brazilian authorities have also tried to remove the fundamental causes of organized crime: economic inequality, poverty, unemployment, low level of education and easy access to drugs and weapons. However, after several years of decline, the level of violence is rising (see Graphs 1 and 3 ), especially in the north-eastern region of Brazil and in the country's largest cities. According to experts, the economic recession, the rise in unemployment and the corruption scandals, involving the highest political and corporate elites, have also contributed to the rising rates of violent crime. Moreover, Brazilian authorities must face the threat posed by large domestic criminal groups, like Primeiro Comando da Capital or Comando Vermelho, who are involved in the international drugs trade. A brutal fight between rival drug gangsters and the police contributes to the high level of homicide rates, including accidental victims as well.

The primary institutions of the Brazilian criminal justice system are the law enforcement, prosecution, defense lawyers and the courts. In accordance with the Constitution, the state police forces (Civil and Military) are predominately responsible for maintaining public order and preventing, detecting and investigating criminal activities. It is worth adding that Brazilian Armed Forces are also regularly used to support police in the fight against criminal groups.

However, many researchers recognize the need for a reform of the police and judicial system to make the struggle against organized crime more effective. They mainly criticize the poor training, the insufficient investment in equipment and the poor wages for lower ranking police officers. These are the reasons why some of the policemen work additionally as private security guards or as "militia" members. Moreover, there is a growing dissatisfaction with corruption in police forces and the resort to excessive violence. Additionally, there is still much to be done to improve the efficiency of the courts and to reduce the high impunity rates.

It seems that the projects connecting police intervention with social programs have brought positive results. A more visible police presence has resulted in an important drop in crime and the security of people has improved. Consequently, the local authorities could start providing social services such as schools, healthcare centers or rubbish collection. Moreover, the crime prevention programs have been introduced, especially among young population (Cano 2006). But the implementation of the programs depends on the proper financing and effective management.
The Efforts to Combat Organized Crime in Brazil

Edyta Chwiej 
Adorno L. (2018), Costa F., PCC em expansão, “UOL Notícias”, 7.07.2018, https://www.uol/ noticias/especiais/pcc-o-partido-do-crime.htm\#pcc-em-expansao, access: 7.10.2018.

Agência IBGE (2017), One fourth of the population lives on less than $R \$ 387$ a month, 15.12.2017, https://agenciadenoticias.ibge.gov.br/en/agencia-news/2184-news-agency/news/18835-onefourth-of-the-population-lives-on-less-than-r-387-a-month, access: 2.10.2018.

Albanese J., Reichel P. (2014), Transnational Organized Crime: An Overview from Six Continents, Sage, Thousand Oaks.

Alves R. (2018), Cerimônia marca fim da intervenção federal no RJ: 'Cumprimos a missão', diz general, "G1" 27.12.2018, https://g1.globo.com/rj/rio-de-janeiro/noticia/2018/12/27/ cerimonia-encerra-intervencao-federal-na-seguranca-do-rj.ghtml access: 27.01.2019.

Barbara V. (2014), Pity Brazil's Military Police, “The New York Times”, 19.02.2014, https:// www.nytimes.com/2014/02/20/opinion/barbara-reform-brazils-military-police.html, access: 10.01.2019.

Barrionuevo A. (2008), Militias Replace Gangs as Rio's Crime Lords, "The New York Times" 13.06.2008, https://www.nytimes.com/2008/06/13/world/americas/13iht-brazil.4.13670865. html, access: 9.01.2019.

Borges de Mendonça A. (2014), The Criminal Justice System in Brazil, in: Resource Material Series no 92, T. Akane (red.), United Nations Asia and Far East Institute for the Prevention of Crime and the Treatment of Offenders, https://www.unafei.or.jp/publications/pdf/RS_ No92/No92_00All.pdf, access: 27.01.2019.

Casas-Zamora K. (2013), Dangerous Liaisons: Organized Crime and Political Finance in Latin America and Beyond, Bookings Institution Press, Washington.

Cano I. (2006), Public Security Policies in Brazil: Attempts to Modernize and Democratize versus the War on Crime, "Sur - Revista Internacional de Direitos Humanos", vol. 3, no 5, http://www.scielo.br/scielo.php?script=sci_arttext\&pid=S1806-64452006000200007\&lng= en\&nrm=iso\&tlng=en, access: 8.01.2019.

Cano I. (2013), Violence and Organized Crime in Brazil: The Case of "Militias" in Rio de Janeiro, in: Transnational Organized Crime. Analyses of a Global Challenge to Democracy, H. Böll-Stiftung, R. Schönenberg (red.), Bielefeld.

Carvalho L., Berg L. van den, Galal H., Teunisse P. (2017), Delivering Sustainable Competitiveness: Revisiting the organising capacity of cities, Routledge, Abingdon.

CIA The World Factbook, Country Comparison:Distribution of Family Income-GINIINDEX, https://www.cia.gov/library/publications/the-world-factbook/rankorder/2172rank.html, access: 3.10.2018.

CNN Español (2018), Triste récord para Brasil: la tasa de homicidios alcanzó el nivel más alto de su historia, 5.06.2018, https://cnnespanol.cnn.com/2018/06/05/brasil-homicidiosrecord-tasa-jovenes-asesinatos-violencia/ access: 5.10.2018.

Constituição da República Federativa do Brasil de 1988, Presidência da República, http:// www.planalto.gov.br/ccivil_03/Constituicao/Constituicao.htm, Access: 7.01.2019.

Costa F. C. (2007), The Brazilian Legal Framework for Investigation, Prosecution and Trial of Transnational Organized Crime, in: Resource Material Series No. 73, K. Aizawa (red.), United Nations Asia and Far East Institute for the Prevention of Crime and the Treatment of Offenders, https://www.unafei.or.jp/publications/pdf/RS_No73/No73_00All.pdf, access: 2.01.2019. 
Crositti J. (2012), Brazil Today. An Encyclopedia of Life in the Republic, ABC-CLIO, Santa Barbara.

Darlington S. (2018), A Year of Violence Sees Brazil's Murder Rate Hit Record High, „, The New York Times" 10.08.2018, https://www.nytimes.com/2018/08/10/world/americas/ brazil-murder-rate-record.html, access: 3.10.2018.

Decreto No 9288 de 16 de fevereiro de 2018, Presidência da República, http://www.planalto. gov.br/ccivil_03/_ato2015-2018/2018/decreto/D9288.htm, access: 22.01.2019.

Dias Carneiro J. (2017), Cinco motivos que levaram o Rio à pior crise de segurança em mais de uma década, "BBC Brasil", 5.05.2017, https://www.bbc.com/portuguese/brasil-39816208, access: 24.01.2019.

Diretriz Ministerial No 15/2010, Ministério da Defesa, https://www.defesa.gov.br/ noticias/3587-04122010-defesa-diretriz-ministerial-no-152010, access: 22.01.2019.

Ellis R. E. (2018), Transnational Organized Crime in Latin America and the Caribbean. From Evolving Threats and Responses to Integrated, Adaptive Solutions, Lexington Books, Lanham.

Flynn D., Palermo M. P. (2017), Brazil aims to build 30 prisons this year to tackle crisis: Temer, "Reuters", 16.01.2017, https://www.reuters.com/article/us-brazil-temer-prisons/ brazil-aims-to-build-30-prisons-this-year-to-tackle-crisis-temer-idUSKBN1502HD, access: 10.10.2018.

"Folha de S. Paulo" (1994) Operação Rio, 22.11.1994, https://www1.folha.uol.com.br/ fsp/1994/11/22/opiniao/1.html, Access: 18.01.2019.

Godoy M. (2017), Ação controlada foi criada para combater crime organizado, "O Estado de S. Paulo", 19.05.2017, https://politica.estadao.com.br/noticias/geral,analise-acaocontrolada-foi-criada-para-combater-crime-organizado,70001794575, access: 2.01.2019.

HRW (2013) World Report: Brazil, Human Rights Watch, https://www.hrw.org/worldreport/2013/country-chapters/brazil, access: 10.10.2018.

HRW (2017), Brazil. Events 2017, https://www.hrw.org/world-report/2018/countrychapters/brazil, access: 9.01.2019.

ICPR (2018), The World Prison Brief, Institute for Criminal Policy Research, http://www. prisonstudies.org/highest-to-lowest/prison-population-total?field_region_taxonomy_ tid=All, access: 8.10.2018.

ICPR Brazil (2018), Brazil. World Prison Brief Data, http://www.prisonstudies.org/country/ brazil, access: 8.10.2018.

InSight Crime (2018), Red Command, https://www.insightcrime.org/brazil-organizedcrime-news/red-command-profile/, access: 6.10.2018.

Jordan L. (2012), Brazil Now 2nd in Cocaine, Crack Use: Daily, “The Rio Times”, 6.09.2012, http://riotimesonline.com/brazil-news/rio-politics/brazil-2nd-only-to-us-in-cocainecrack-use/, access: 22.07.2018.

Kassab H. S., Rosen J. D. (2018), Violence in the Americas, Lexington Books, Lanham.

Kontos L., Brotherton D. (2008), Encyclopedia of Gangs, Greenwood Press, Westport, Conn.

Leeds E. (2016), The Brazilian Prison System: Challenges and Prospects for Reform, InSight Crime, 30.12.2016, https://www.insightcrime.org/news/analysis/the-brazilian-prisonsystem-challenges-and-prospects-for-reform/, access: 10.10.2018.

Lei Complementar No 97 de 9 de julho de 1999, Presidência da República, http://www. planalto.gov.br/ccivil_03/LEIS/LCP/Lcp97.htm, Access: 16.01.2019.
The Efforts to Combat Organized Crime in Brazil

Edyta Chwiej 
Lei No 9034 de 3 de maio de 1995, Presidência da República, http://www.planalto.gov.br/ ccivil_03/LEIS/L9034.htm, access: 2.01.2019.

Lei No 10217 de 11 de abril de 2001, Presidência da República, http://www.planalto.gov.br/ ccivil_03/LEIS/LEIS_2001/L10217.htm, Access: 3.01.2019.

Lei No 12850 de 2 de agosto de 2013, Presidência da República, http://www.planalto.gov.br/ ccivil_03/_ato2011-2014/2013/lei/112850.htm, access: 21.07.2018.

Long W. R. (1988), "Animal" Lottery: A "Mafia" Thrives on Brazil Game, "Los Angeles Times", 12.07.1998, http://articles.latimes.com/1988-07-12/news/mn-5691_1_luckynumbers, access: 25.07.2018.

Mazui G., Barbiéri L. F. (2019), Bolsonaro assina decreto que facilita posse de armas, "G1", 15.01.2019, https://g1.globo.com/politica/noticia/2019/01/15/bolsonaro-assina-decretoque-facilita-posse-de-armas.ghtml, access: 5.02.2019.

Margolis M. (2017), Brazil's Narrative of Equality Is Oversold, 29.09.2017, https://www. bloomberg.com/view/articles/2017-09-29/brazil-s-narrative-of-equality-is-oversold, access: 2.10 .2018 .

Mattoso C., Della Coletta R. (2019), Justice Minister Says New Self-Defense Bill "Is Not A License To Kill”, „Folha de S. Paulo", 5.02.2019, https://www1.folha.uol.com.br/internacional/en/ brazil/2019/02/justice-minister-says-new-self-defense-bill-is-not-a-license-to-kill.shtml?utm_ source=newsletter\&utm_medium=email\&utm_campaign=newsen, access: 6.02.2019.

Melo L., Miotto R. (2019), Repercussão do projeto anticrime de Sérgio Moro: o que disseram entidades e políticos, "G1", 4.02.2019, https://g1.globo.com/politica/noticia/2019/02/04/ projeto-anticrime-de-sergio-moro-veja-repercussao.ghtml, access: 6.02.2019.

Muggah R. (2018), Military intervention won't solve the violence in Rio de Janeiro, Instituto Igarapé, 2.03.2018, https://igarape.org.br/military-intervention-wont-solve-the-violencein-rio-de-janeiro/, access: 5.02.2019.

Muggah R. (2016), The State of Security and Justice in Brazil, "Working Paper Series" No 4, Elliot School of International Affairs, The George Washington University, https:// igarape.org.br/wp-content/uploads/2016/04/The-State-of-Security-and-Justice-in-BrazilReviewing-the-Evidence.pdf, access: 7.01.2019.

Oliveira Fernandes E. (2012), As Ações Terroristas do Crime Organizado, Livrus, São Paulo.

Pearson S. (2016), Brazil hopes gambling will reverse its fortunes, "Financial Times", 5.09.2016, https://www.ft.com/content/646bac98-6d72-11e6-a0c9-1365ce54b926, access: 26.07.2018.

Penglase B. (2014), Living with Insecurity in a Brazilian Favela. Urban Violence and Daily Life, Rutgers University Press, New Brunswick.

Phillips D. (2018), "Lesser Evil": How Brazil's Militias Wield Terror to Seize Power from Gangs, “The Guardian”, 12.07.2018, https:/www.theguardian.com/world/2018/jul/12/ brazil-militia-paramilitary-wield-terror-seize-power-from-drug-gangs, access: 9.01.2018.

Pion-Berlin D., Carreras M. (2017), Armed Forces, Police and Crime-fighting in Latin America, "Journal of Politics in Latin America", 9 (3), pp. 3-26.

Prada P. (2006), 5 Days of Violence by Gangs in São Paulo Leaves 115 Dead Before Subsiding, "The New York Times", 17.05.2006, https://www.nytimes.com/2006/05/17/world/americas/17brazil. html, access: 8.10.2018.

"UOL Notícias" (2019), Projeto de Moro ignora temas importantes, diz Fórum de Segurança Pública, "UOL Notícias", 4.02.2019, https://noticias.uol.com.br/politica/ultimas-noti- 
cias/2019/02/04/projeto-moro-ignora-temas-importantes-forum-brasileiro-de-segurancapublica.htm, access: 6.02.2019.

Resende P. (2018), Policiais reclamam que têm o salário mais baixo do país e dormem em delegacias de Goiás por não ter dinheiro para aluguel, "G1”, 22.01.2018, https://g1.globo.com/ go/goias/noticia/policiais-reclamam-que-tem-o-salario-mais-baixo-do-pais-e-dormemem-delegacias-de-goias-por-nao-ter-dinheiro-para-aluguel.ghtml, access: 10.01.2019.

Riccio V., Skogan W. G. (2018), Police and Society in Brazil, Routledge, New York.

Roth M. P. (2017), Global Organized Crime. A 21st Century Approach, Routledge, New York.

Samset I. (2014), For the Guarantee of Law and Order: The Armed Forces and Public Security in Brazil, CMI Working Paper, WP 2014:11, https://www.cmi.no/publications/file/5241for-the-guarantee-of-law-and-order.pdf, access: 16.01.2019.

Secretaria-Geral da Presidência, (2018), Custos Econômicos da Criminalidade no Brasil, http://www.secretariageral.gov.br/estrutura/secretaria_de_assuntos_estrategicos/ publicacoes-e-analise/relatorio-de-conjuntura/custos_economicos_criminalidade_brasil. pdf, access: 11.11.2018.

Stargardter G., Berlowitz P. (2018), Brazil Suffers Record Murder Tally in 2017, Ahead of Election, „Reuters”, 10.08.2018, https://www.reuters.com/article/us-brazil-violence-murder/brazil-suffers-record-murder-tally-in-2017-ahead-of-election-idUSKBN1KU2R5, access: 3.10 .2018 .

Thaty M., Doederlein M. (2017), Policiais militares paulistas reclamam de falta de estrutura e salários baixos, Câmara dos Deputados, 5.07.2017, http://www2.camara.leg.br/camaranoticias/ noticias/SEGURANCA/537426-POLICIAIS-MILITARES-PAULISTAS-RECLAMAM-DEFALTA-DE-ESTRUTURA-E-SALARIOS-BAIXOS.html, access: 10.01.2019.

The Brazilian Report (2018), Who Are the People Working for Drug Cartels in Rio?, 3.08.2018, https://brazilian.report/society/2018/08/03/drug-cartels-rio-de-janeiro/, access: 5.10.2018.

The Economist (2012), Betting Zoo - Illegal Gambling in Brazil, 5.05.2012, https://www. economist.com/the-americas/2012/05/05/betting-zoo, access: 27.07.2018.

The New York Times (2019), Brazil Minister Proposes Tougher Laws to Stem Deadly Crime Wave, 4.02.2019, https://www.nytimes.com/reuters/2019/02/04/world/americas/04reutersbrazil-politics-crime.html, access: 5.02.2019.

UNDP (2018), Human Development Indices and Indicators 2018: Brazil, http://hdr.undp. org/sites/all/themes/hdr_theme/country-notes/BRA.pdf, access: 4.10.2018.

UNODC (2011), Estimating Illicit Financial Flows Resulting from Drug Trafficking and Other Transnational Organized Crimes, http://www.unodc.org/documents/data-and-analysis/ Studies/Illicit_financial_flows_2011_web.pdf p. 7, access: 21.07.2018.

UNODC (2004), United Nations Convention Against Transnational Organized Crime and The Protocols Thereto, https://www.unodc.org/documents/treaties/UNTOC/Publications/ TOC\%20Convention/TOCebook-e.pdf, access: 17.07.2018.

Velasco C., Caesar G., Reis T. (2018), Cresce número de pessoas mortas pela polícia no Brasil; assassinatos de policiais caem, "G1" 10.05.2018, https://g1.globo.com/monitor-daviolencia/noticia/cresce-numero-de-pessoas-mortas-pela-policia-no-brasil-assassinatosde-policiais-caem.ghtml, access: 9.01.2019.

Waiselfisz J. J. (2016), Mapa da Violência, FLASCO Brasil, https://www.mapadaviolencia. org.br/pdf2016/Mapa2016_armas_web.pdf, access: 1.01.2019.
The Efforts to Combat Organized Crime in Brazil

Edyta Chwiej 
Woody Ch. (2018), Latin America's Biggest Port Just Made Its Largest Cocaine Seizure Ever the Latest Bust in a Thriving Drug-trafficking Corridor, "Business Insider", access: 23.03.2018.

World Bank (2015), Brazil Literacy Rate, Adult Total (\% of People Ages 15 and above), https://data.worldbank.org/indicator/SE.ADT.LITR.ZS?locations=BR, access: 4.10.2018.

World Bank (2018), GDP per Capita, PPP, https://data.worldbank.org/indicator/NY.GDP. PCAP.PP.CD, access: 2.10.2018. 